\title{
FROST WEATHERING OF SELECTED ROCKS FROM THE TATRA MOUNTAINS
}

\author{
EWA LUBERA \\ Institute of Geography and Spatial Management, Jagiellonian University, Cracow, Poland \\ Manuscript received: January 07, 2014 \\ Revised version: February 22, 2014
}

LubERA E., 2014. Frost weathering of selected rocks in the Tatra Mountains. Quaestiones Geographicae 33(1), Bogucki Wydawnictwo Naukowe, Poznań, pp. 75-88, 13 figs, 10 tables. DOI 10.2478/quageo-2014-0003, ISSN 0137-477X

ABSTRACT: The paper summarises the progress of a frost weathering simulation experiment involving a range of rocks after more than 300 gelation cycles. Samples of granite, conglomerate, sandstone, dolomite, limestone and amphibolite were sourced in the Chochołowska Valley, Tatra Mts. The simulation project, which continues at the Low Temperature Laboratory of the Jagiellonian University, Cracow, is set to quantify the resistance of the rocks to frost weathering by measuring the number of gelation cycles after which the samples are damaged. At the end of the project, the degree of damage will be assessed using the percentage loss of the initial sample weight and a frost weathering indicator. So far, little damage has been recorded overall, with the dolomite samples losing the highest percentage of their initial weight at nearly $6 \%$. The paper also presents results of physical tests of the rocks, including their strength, porosity and density, which provide a useful insight into the interpretation of differences in frost weathering resistance.

KEY WORDS: frost weathering, rock properties, laboratory simulation, Western Tatra Mountains

Address of the corresponding author: Ewa Lubera, Institute of Geography and Spatial Management, Jagiellonian University, Gronostajowa 7, 30-387 Cracow, Poland, e-mail: ewa.lubera@uj.edu.pl

\section{Introduction}

Like all types of physical weathering, frost weathering leads to a reduction or loss of cohesion in rocks without changing their mineral and chemical composition. Frost weathering manifests itself by a gradual opening of existing surface discontinuities and the development of new ones. This, in turn, leads to fragmentation and separation of various-sized rock fragments that either remains in situ or is displaced in various morphogenetic processes (Migoń 2006). Frost weathering, as a preparatory process, plays a very important role in the morphogenesis of mountain areas. The course of frost weathering depends primarily on climatic conditions, rock properties, orographic conditions and ex- posure, and time. Frost weathering is regarded as a permanent, low rate secular process (Kotarba 2002).

The objective of the study is to determine the resistance to frost weathering of selected rocks from the Tatra Mountains. In contrast to existing studies, which only provide qualitative information on frost weathering in the Tatra Mountains, this study is designed to offer quantitative results through detailed laboratory testing, including the simulation of frost weathering and ultrasound testing. In order to determine the causes of any differences in the resistance to frost weathering, the physical properties of the rock samples were analysed, including strength, open porosity, absorbability and volume density, as well as petrography. 


\section{State of research}

Large scale research on the nature, course and effects of frost weathering started in the 1960s (Tricart 1960, Viman 1963, Martini 1967). Early laboratory simulations were intended to recreate Siberian or Icelandic climates and to evaluate the influence of temperature and humidity on frost weathering. Consideration was given to the importance of the choice of temperature ranges, access to water during freezing, rate of freezing and what level of negative temperatures was necessary to trigger processes leading to rock breakup (Tricart 1960, Lautridou, Ozouf 1982, Matsuoka 1990a, 1991, 2001).

Tricart (1960) performed weathering experiments on rock samples from the Paris Basin, Jura Mts., Rhone Valley, Southern Alps and Vosges Mountains. As a result chalk, chalky limestone and some oolite and marly limestone rocks decomposed entirely, while other samples remained nearly intact (Table 1). The research has demonstrated that it was the expansion of water volume during freezing rather than temperature change, which was the most important factor in the outcome of frost weathering. Also higher rates of freezing failed to result in a greater scale of breakup (Lautridou, Ozouf 1982). Frost

Table 1. Products of experimental frost weathering in wet conditions (Tricart 1960, amended)

\begin{tabular}{|l|c|}
\hline \multicolumn{2}{|c|}{ Siberian type, wet environment, 10 cycles } \\
\hline Chalk, Vitry-le-Fr. & $\begin{array}{c}\text { Waste rock } \\
\text { produced [\%] }\end{array}$ \\
\hline Chalk, Camiers & 100.00 \\
\hline Chalky limestone, Chatel-Censoir & 100.00 \\
\hline Marly limestone, Ligny-en-Barrois & 100.00 \\
\hline Oolitic marly limestone, Duaumont & 4.50 \\
\hline Dolomite, Merry-sur-Yonne & 100.00 \\
\hline Compact limestone, Le Sautet & 10.22 \\
\hline Sandstone limestone, Souspierre & 1.21 \\
\hline Molasse, Les Baux & 0.69 \\
\hline Hauterivian, Barbentane & 2.25 \\
\hline Oolitic limestone, Baalons & 4.05 \\
\hline Muschelkalk, St. Claude & 6.63 \\
\hline Buntsandstein, Lutzelburg & 5.83 \\
\hline Porphyry, Mont Vinaigre & 3.40 \\
\hline
\end{tabular}

weathering was faster in wet environments and produced more waste rock than in dry conditions (Table 2, Tricart 1960).

Martini (1967) conducted his experimental studies on the susceptibility of various types of granitoid, schist, gneiss, basalt, greenstone and limestone rocks to frost weathering. The rocks were sampled in the Karkonosze Mountains, Jeleniogórska Basin, Kaczawskie Mountains and Izerskie Mountains and subjected to a temperature range of $-7^{\circ} \mathrm{C}$ to $+6^{\circ} \mathrm{C}$ and half immersed in water. Fine-grained granites, schists, crystalline limestones, gneiss and volcanic rocks displayed the highest resistance (less than 1\% waste rock in total sample weight), while sandstone and weathered granite rocks were the most susceptible.

Lautridou and Ozouf (1982) simulated frost weathering in two low temperature laboratories chilling the samples to $-8^{\circ} \mathrm{C}$ and to $-28^{\circ} \mathrm{C}$. Sandstone, granite, shale, volcanic and limestone rocks were taken from, among other sources, the Alps, the Massif Central, Normandy, the Pyrenees, the Vosges and Lofoten. The greatest amounts of fine material are produced by chalks, marly limestones and molasse sandstones. Unweathered schists produce very little fine debris, less than $2 \%$. Weathered granites can produce clay and silt-sized material. The chalky limestone rocks decomposed between the $20^{\text {th }}$ and $30^{\text {th }}$ gelation cycles, lithographic limestones between the $30^{\text {th }}$ and $60^{\text {th }}$, nummulite limestones after 100 cycles and muschelnkalk after 200 cycles.

Evin (1987) subjected seven rock samples from the south-western Alps to multi-gelation. The samples were first tested for porosity and ultrasound properties. The temperatures used ranged from $-12^{\circ} \mathrm{C}$ to $+15^{\circ} \mathrm{C}$ and each gelation cycle lasted 24 hours producing the following results: marble 87 cycles, sandstone 229 cycles and volcanic schist 361 cycles. Quartzite rocks did not break up after 300 to 500 cycles (Table 3).

Matsuoka (1990a) simulated frost weathering on 47 rock samples including sedimentary, volcanic and metamorphic rocks. Both wet and dry conditions were provided and the temperature range was set at $-20^{\circ} \mathrm{C}$ to $+20^{\circ} \mathrm{C}$. Ultrasonic $\left(\mathrm{V}_{\mathrm{p}}\right)$ measurements were performed to determine any deterioration in the sample. The $V_{p}$ measured after 50 gelation cycles showed that rocks subjected to the experiment in the dry system suffered little 
Table 2. Frost weathering effects in Icelandic and Siberian climate types (Tricart 1960, amended)

\begin{tabular}{|c|l|c|c|c|c|c|c|}
\hline \multicolumn{2}{|c|}{ Type of climate } & \multicolumn{3}{c|}{ Icelandic } & \multicolumn{3}{c|}{ Siberian } \\
\hline \multicolumn{2}{|c|}{ Number of cycles } & \multicolumn{3}{|c|}{25} & in silt & in water \\
\hline \multirow{2}{*}{ Environment } & dry & in silt & in water & dry & none & $1.3 \%$ & $29.0 \%$ \\
\hline \multirow{3}{*}{ Rock } & Muschelnkalk & none & $5.0 \%$ & $8.1 \%$ & none & $1.0 \%$ & $11.3 \%$ \\
\cline { 2 - 8 } & Sandy spongolite & none & $1.5 \%$ & $3.8 \%$ & none & little & $0.25 \%$ \\
\cline { 2 - 8 } & Bunter sandstone & none & little & $0.17 \%$ & ne \\
\hline
\end{tabular}

Table 3. Rock weathering test data (Evin 1987)

\begin{tabular}{|c|c|c|c|c|c|c|}
\hline Rock type & quartzites & $\begin{array}{l}\text { pink augen } \\
\text { marble }\end{array}$ & $\begin{array}{l}\text { dark grey strong } \\
\text { limestone }\end{array}$ & $\begin{array}{c}\text { green volcanic } \\
\text { schist }\end{array}$ & sandstone & $\begin{array}{l}\text { green } \\
\text { rocks }\end{array}$ \\
\hline $\begin{array}{c}\text { porosity } \\
{[\%]}\end{array}$ & 0.5 & 0.66 & 4.51 & 1.31 & 1.01 & $0.5-1.2$ \\
\hline \multicolumn{7}{|l|}{ cycle 23} \\
\hline cycle 32 & & & little crack at base of sample & & & \\
\hline cycle 46 & & & large crack & & & \\
\hline cycle 87 & & & 4 pieces & & & \\
\hline cycle 153 & & & numerous pieces & & small amount scale & \\
\hline cycle 229 & & & blocks burst & 2 little scales & $1.5 \mathrm{~g}$ sand & \\
\hline cycle 361 & & & disaggregated & some sand & & \\
\hline cycle 480 & & & & $1 \mathrm{~g}$ sand & $4.5 \mathrm{~g}$ sand & \\
\hline cycle 729 & nothing & nothing & & & $5.5 \mathrm{~g}$ sand & nothing \\
\hline
\end{tabular}

damage, as opposed to the wet system, where the changes were significant (Fig. 1).

Matsuoka (1991, 2001) also conducted research intended to identify the temperatures, at which water freezes within rock. It was found that the largest proportion of pore water froze at between $0^{\circ} \mathrm{C}$ and $-5^{\circ} \mathrm{C}$. Highly porous rocks broke up in negative temperatures close to zero. The breakup began at $0^{\circ} \mathrm{C}$ to $-1^{\circ} \mathrm{C}$ and continued until the temperature reached about $-5^{\circ} \mathrm{C}$. In medium-porosity rocks these temperatures ranged from $-3^{\circ} \mathrm{C}$ to $-6^{\circ} \mathrm{C}$, while in low-porosity rocks this occurred at $-4^{\circ} \mathrm{C}$.

Numerous studies focused on the analysis of the mechanisms of rock breakup, i.e. the $9 \%$ increase in volume during water phase change and thermal stress (Bland, Rolls 1998, Hall 1999, 2002) and cryosuction (Everett 1961, Walder, Hallet 1985, Selby 1993, Warke 2000, Andrén 2006, Murton et al. 2006).

For a long time, the $9 \%$ increase in water volume during its phase change into ice was regarded as the main cause of frost weathering. Water increases its volume as its molecules assume a hexagonal crystalline form as it turns from a liquid into a solid state. Everett (1961) offered an alternative process leading to rock breakup. It involved free water freezing between aggregates of mineral grains at $0^{\circ} \mathrm{C}\left(-0.2^{\circ} \mathrm{C}\right)$. Unfrozen capillary and adhesion water between mineral aggregates is sucked towards the ice. As more

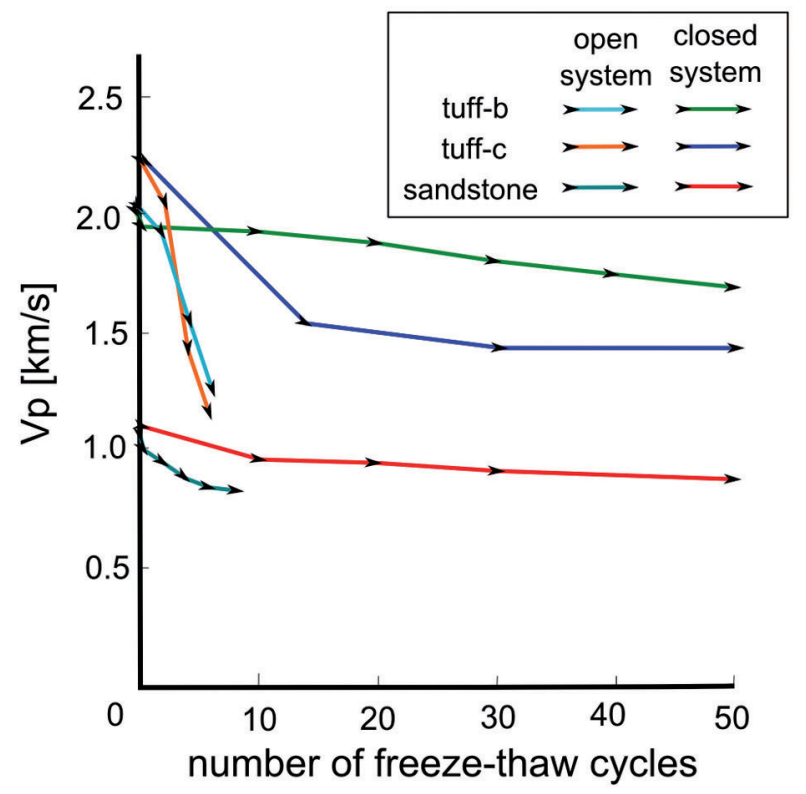

Fig. 1. Reduction of longitudinal wave velocity of rocks during 50 freeze-thaw cycles: comparisons between open and closed systems (Matsuoka 1990a) 
and more water molecules turn into ice, the size of ice clusters grows, the tension within the rock medium increases, the existing cracking expands and new ones develop (Murton et al. 2006).

Thermal stress has been suggested as yet another cause of rock breakup. As the rock cools down, its surface is subjected to tensile forces, while the rock centre is subjected to compression. A reverse process occurs during rock warming. The rock centre cools at a much slower rate than its surface leaving a certain temperature differential between the two extremes. This differential generates stress within the rock (Hall 1999, 2002).

A number of studies focused on identifying which rock properties influenced the rock susceptibility to frost weathering. The most frequently quoted properties include: texture, mineral composition, permeability, porosity, compression and tension strength, existing cracking, heat conductibility and the degree of weathering (Martini 1967, Lautridou, Ozouf 1982, Matsuoka 1990a, 1991, Hall 1992, André 1996, Bland, Rolls 1998, Matsuoka 2001, Prick et al. 2003, Whalley, Warke 2005). The dependence between the rock texture and susceptibility to frost weathering varies. Breakup patterns tend to be linked to directional texture, but some rocks were observed to display neutrality of the original rock texture to frost weathering (Tricart 1960). The proportion of minerals with certain degrees of resistance was also found to be significant, including highly resistant quartz, muscovite and biotite; medium-resistance plagioclase; and low-resistance hornblende, augite and olivine (Whalley, Warke 2005). Permeability, open porosity and degree of cracking have an impact on water penetration and, consequently, rock susceptibility to the kind of frost weathering that is caused by the $9 \%$ vol-

Table 4. Strength properties of rocks (Selby 1993)

\begin{tabular}{|l|c|c|}
\hline \multirow{2}{*}{\multicolumn{1}{|c|}{ Rock }} & \multicolumn{2}{c|}{ Strength (MPa) } \\
\cline { 2 - 3 } & Compression & Tension \\
\hline Granite & $100-250$ & $7-25$ \\
\hline Basalt & $150-300$ & $10-30$ \\
\hline Gneiss & $50-200$ & $5-20$ \\
\hline Schist & $100-200$ & $7-20$ \\
\hline Crystalline limestone & $100-250$ & $7-20$ \\
\hline Shale & $100-200$ & $7-20$ \\
\hline Sandstone & $20-170$ & $4-25$ \\
\hline
\end{tabular}

ume increase and ice segregation. The thermal conductivity of the rock was important where the breakup occurred primarily through thermal stress. The strength properties of the rock determined the rock resistance to stress generated within the rock as a result of thermal and volumetric change and cryosuction. Pressure levels caused by water migration and the expansion of the ice lens can exceed $20 \mathrm{MPa}$, i.e. more than the tension strength of most rocks (Table 4, Selby 1993).

\section{Study area}

Rock samples were taken from Dolina Chochołowska, the largest and westernmost valley of the Polish Tatras, which cuts through sedimentary, crystalline and metamorphic rocks. The rocks were sampled in six locations: the northern slopes of Mt. Wołowiec, Mt. Dudowe Turnie and Mt. Mnichy Chochołowskie, the lower sections of the southern slopes of Mt. Kominiarski Wierch, the lower sections of the southern slopes of Mt. Grześ and the slopes of the Dudowa Valley above the Międzyściany Gorge. The samples were taken from the cliffs or from the foot of rock outcrops (Table 5, Fig. 2).

Table 5. Rock sampling sites for frost weathering tests

\begin{tabular}{|c|l|c|l|}
\hline $\begin{array}{c}\text { Sam- } \\
\text { ple }\end{array}$ & \multicolumn{1}{|c|}{ Location } & $\begin{array}{c}\text { Altitude } \\
\text { m a.s.l. }\end{array}$ & \multicolumn{1}{|c|}{ Lithology* } \\
\hline 6 & Kominiarski & 1115 & $\begin{array}{l}\text { Fine-grained con- } \\
\text { glomerate }\end{array}$ \\
\hline 7 & Dudowa Valley & 1125 & $\begin{array}{l}\text { Organic-detrital } \\
\text { limestone }\end{array}$ \\
\hline 2 & Grześ & 1175 & Quartzite sandstone \\
\hline 1 & Mnichy Ch. & 1465 & Dolomite breccia \\
\hline 4 & Wołowiec & 1630 & Amphibolite \\
\hline 3 & Wołowiec & 1635 & White granite \\
\hline 5 & Dudowe Turnie & 1645 & Brown granite \\
\hline
\end{tabular}

*Samples analysed under the optical microscope at the Department of Mineralogy, Petrology and Geochemistry, Jagiellonian University

\section{Methods}

Five to six cores were produced from each raw sample, with a height and basal diameter of $5 \mathrm{~cm}$. One of the cores of each rock type was used to produce smaller cores for compressive and 


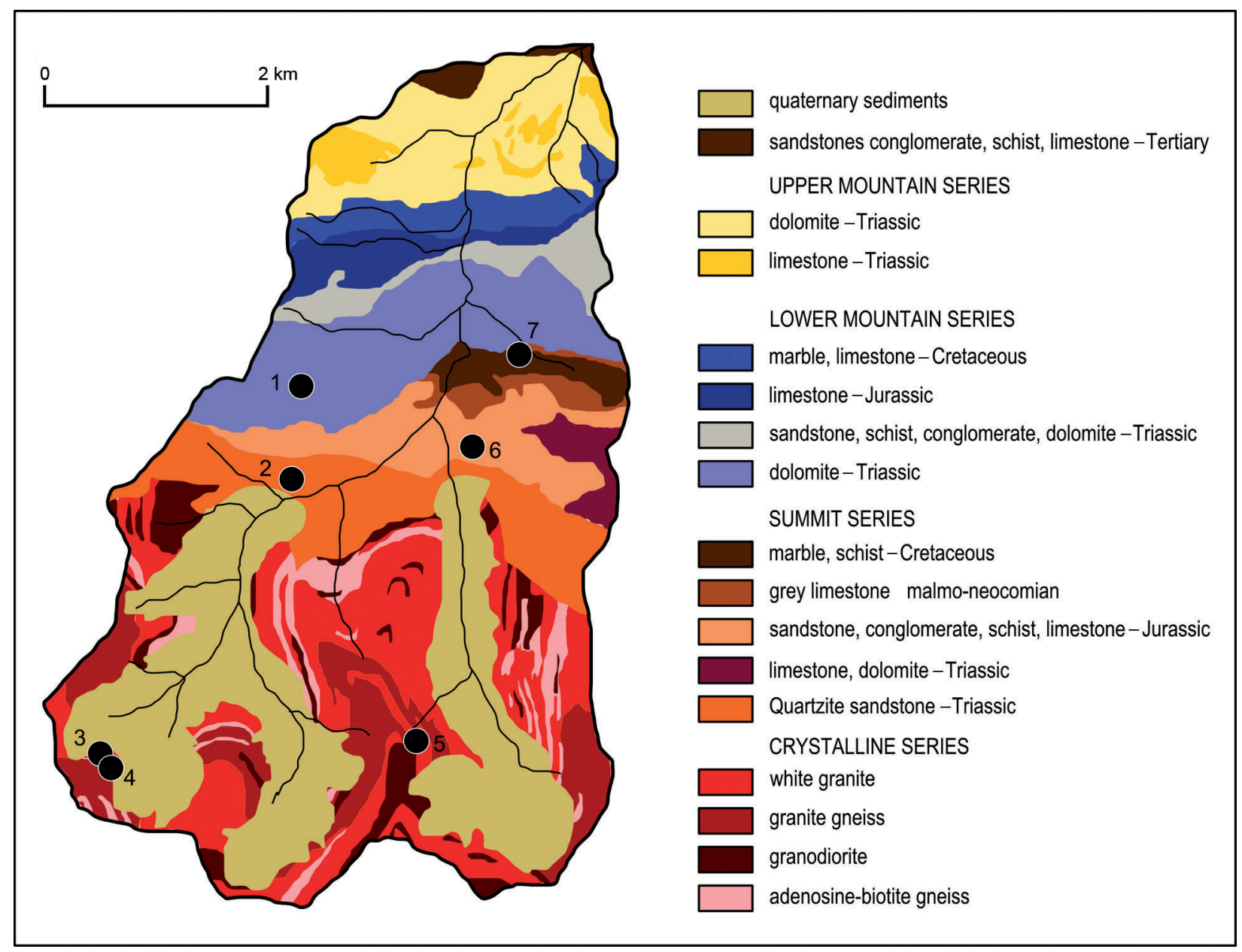

Fig. 2. Geological map of the Chochołowska Valley and sampling sites (based on Michalik 1985)

tensile strength testing (Fig. 3). The remaining cores were used to determine their open porosity, volumetric density and for petrographic and diffraction analysis.

Single-axis compressive and tensile strength tests were performed at the Strata Mechanics Research Institute of the Polish Academy of Sciences. The uniaxial compression test involves placing a sample between the moving plates of the strength press. The shortening of the sample and its lateral expansion are measured. The tension strength test involves compressing the sample with a force directed along the diagonal (Kisiel 1982). The compressing force generates lateral stress within the sample, which is split into halves.

Tensile and compressive strengths are considered to be among the most important properties of rocks, as they represent the rock's degree of resistance to pressures exerted during water phase changes (Lautridou, Ozouf 1982, Matsuoka 1990b, Matsuoka 1991).
Sample porosity was determined using a water saturation method based on a study by Chen et al. (2004). The measurements were performed at the Department of Hydrogeology and Engineering Geology, Faculty of Geology, Geophysics and Environment Protection, University of Science and Technology. First, the samples were dried at $105^{\circ} \mathrm{C}$ and weighed, after which they were saturated with water and weighed in air and in water. Their porosity was calculated using the formula:

$$
\mathrm{n}_{\mathrm{o}}=\left(\mathrm{G}_{\mathrm{p}}-\mathrm{G}_{\mathrm{s}} / \mathrm{G}_{\mathrm{p}}-\mathrm{G}_{\mathrm{w}}\right) \cdot 100 \%
$$

where:

$\mathrm{n}_{\mathrm{o}}$ - open porosity coefficient [\%],

$\mathrm{G}_{\mathrm{p}}$ - weight of water-saturated sample in air [g],

$\mathrm{G}_{\mathrm{s}}$ - weight of dry sample in air [g],

$\mathrm{G}_{\mathrm{w}}$ - weight of water-saturated sample in water [g].

Porosity and degree of saturation have an influence on the $9 \%$ volume increase during the 
water phase change and on the rate of water migration towards the freezing fronts. For a low porosity rock to breakup it must have some cracking (Lautridou, Ozouf 1982, Matsuoka 1990a, 1991, 2001, Prick et al. 2003, Murton et al. 2006).

The samples were analysed under the optical microscope at the Department of Mineralogy, Petrology and Geochemistry, Jagiellonian University in order to determine their mineral composition, structure and texture.

Research of this type provides important information about:

- the concentration of quartz, muscovite and biotite, i.e. minerals known for their high resistance to weathering, as a proportion of the overall mineral composition;

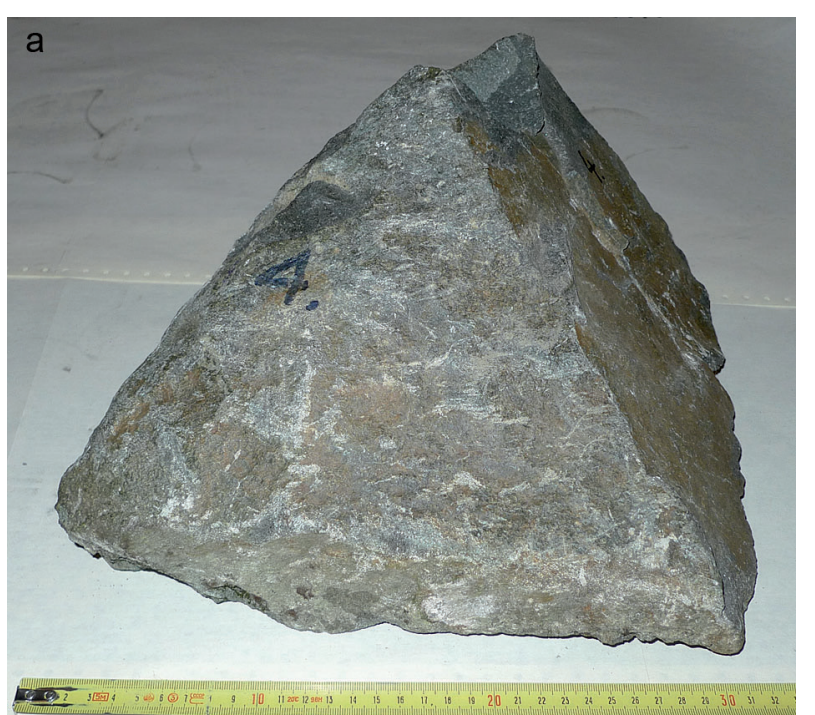

- any texture directionality that may encourage the rock to break up;

- the filling of pores with a binder (Martini 1967, André 1996, Bland, Rolls 1998, Whalley, Warke 2005).

The frost weathering simulation began in February 2011 at the Low Temperature Laboratory, Jagiellonian University, using a CI/1400/ LT/2D freezer with an STE 3 temperature controller manufactured by JBG-2. The simulation involves 31 rock samples, including 4-5 samples from each rock type. Two gelation cycles are programmed every 24 hours and the temperatures change between $-5^{\circ} \mathrm{C}$ and $+10^{\circ} \mathrm{C}$. The extreme temperatures are maintained for five hours. The saturated rock samples are placed $2 \mathrm{~cm}$-deep in distilled water in plastic containers covered for the duration of the simulation to maintain humidity.

A set of measurements is performed every 100 cycles to detect changes in the rock samples. The measurements include: dry weight $(\mathrm{m})$ water-saturated weight $\left(\mathrm{m}_{\mathrm{w}}\right)$, water absorption capacity $\left(A_{b}\right)$, wave damping coefficient $(A)$, specific electrical conductivity (SEC) of the water in wet containers (using a WTW 3110 conductometer with a Con 325 electrode) and an ultrasonic test. The conductivity measurement is intended to determine the role of rock dissolution. The water was also analysed for its ion composition at the Faculty of Forestry, University of Agriculture, Cra-

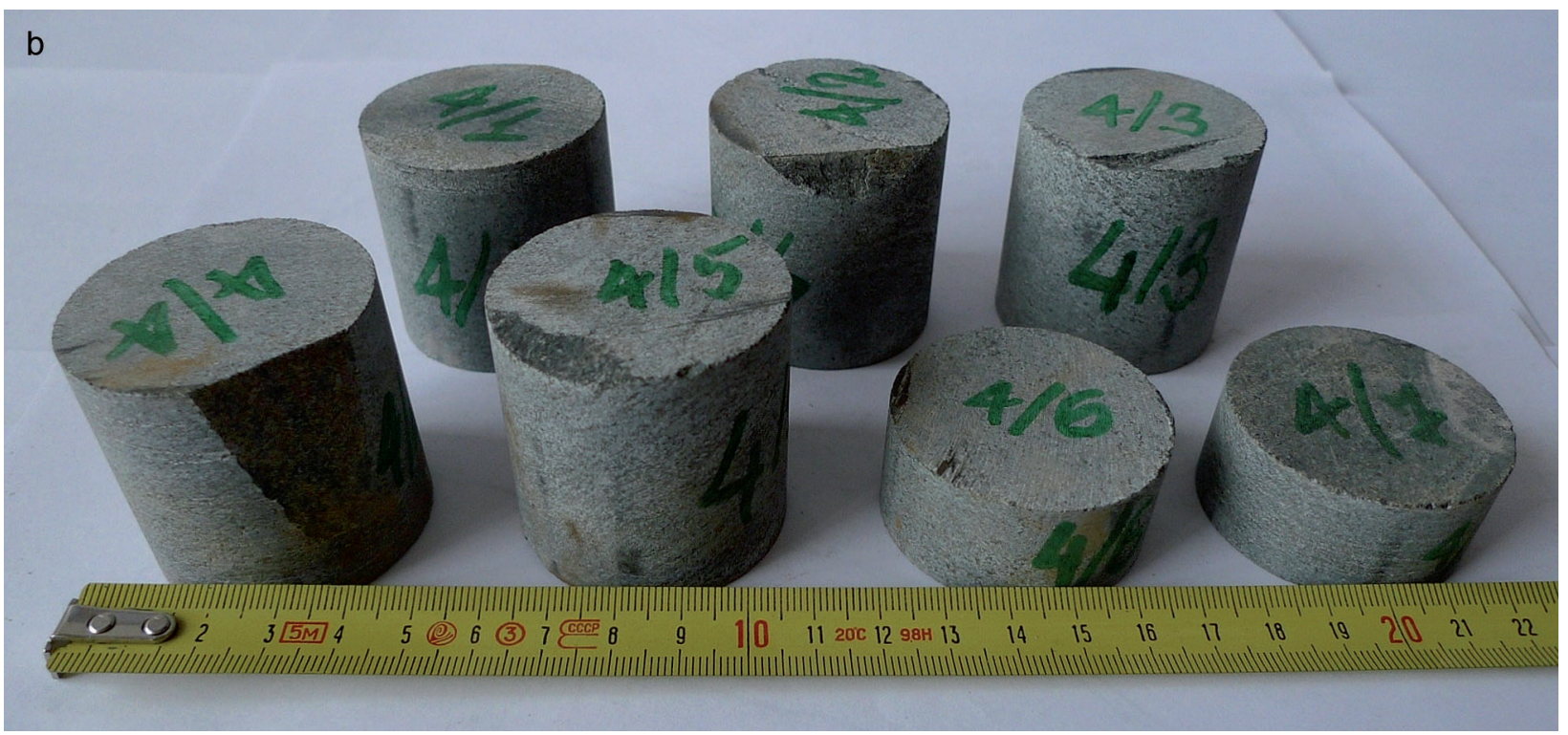

Fig. 3. Raw field sample (a) and cores produced for weathering analysis and strength testing (b) - amphibolite 
cow. The ultrasonic testing procedure involves a number of steps: drying of the samples at $75^{\circ} \mathrm{C}$ for $48 \mathrm{~h}$, weighing them when fully dry, performing an ultrasonic test, placing the samples in a vacuum to extract air from the pores (until mass is stabilised) and resaturating with water. This is followed by weighing the wet samples $\left(\mathrm{m}_{\mathrm{w}}\right)$ to check their absorption capacity.

The ultrasonic test involves a measurement of a longitudinal acoustic wave as it passes through the sample $\left(\mathrm{V}_{\mathrm{p}}\right)$. This is one of the non-destructive tests used to assess whether the procedure applied causes changes in the test samples (Nowakowski et al. 2003) and to detect any deterioration in the condition of the rock samples during the laboratory experiments (Matsuoka 1990a). The wave velocity measurement is done by placing the sample between two steel irons equipped with a transmitter and receiver of the longitudinal acoustic wave and measuring the wave passage time. The velocity of the longitudinal wave $\left(\mathrm{V}_{\mathrm{p}}\right)$ is obtained by dividing the height of the sample $(\mathrm{h})$ by the real time $\left(\mathrm{t}_{\mathrm{p}}\right)$, which is equal to the measured time $\left(t_{z}\right)$ minus dead time $\left(t_{0}\right)$. Structural discontinuities, i.e. cracking, grain boundaries, precipitation and pores cause a small portion of the ultrasound energy to be deflected from the main course (Baranowska, Garbiak 1999). A reduction in the wave speed signals damage to the rock sample (Matsuoka 1990a).

A frost-weathering indicator $\left(R_{f}\right)$ developed by Matsuoka (1990a) will be applied upon completion of the laboratory testing:

$$
\mathrm{R}_{\mathrm{f}}=\left(\mathrm{V}_{\mathrm{p} 0}-\mathrm{V}_{\mathrm{pk}}\right) / \mathrm{V}_{\mathrm{p} 0} \cdot \mathrm{k}\left[\mathrm{cycles}^{-1}\right]
$$

where:

$\mathrm{V}_{\mathrm{p} 0}$ - velocity of an ultrasound P-wave before multi-gelation [ $\left.\mathrm{km} \mathrm{s}^{-1}\right]$,

$\mathrm{V}_{\mathrm{pk}}$ - velocity of an ultrasound P-wave after k cycles $\left[\mathrm{km} \mathrm{s}^{-1}\right]$,

$\mathrm{k}$ - number of gelation cycles.

The indicator and the percentage loss of the initial sample weight determined after a certain number of gelation cycles will help determine the frost weathering susceptibility in Tatra rocks.

For comparative purposes a field experiment is under way, alongside the laboratory-testing programme, which involves placing six rock samples of each type at the sampling locations. Half of the samples involved have a cylindrical shape (identical in size with laboratory samples) and the other half have irregular shapes of a similar volume. The differentiation of the sample form factor is intended to help investigate the impact of rock surface types and the number of edges on frost weathering. The samples were placed in containers with holes in the bottom protected by a dense mesh with an opening size of less than one millimetre to ensure the outflow of drainage and water, while at the same time avoiding the displacement of the waste rock material accumulated (Fig. 4).

The purpose of the field experiment is to determine details and the rate of rock weathering taking into account, in addition to the temperature fluctuations covered in the laboratory, such natural effects as heating by solar radiation, corrosion by water solutions, drying by the wind and thermal insulation by the snow cover.

The experiment involves air temperature measurements, which crucially include a season-

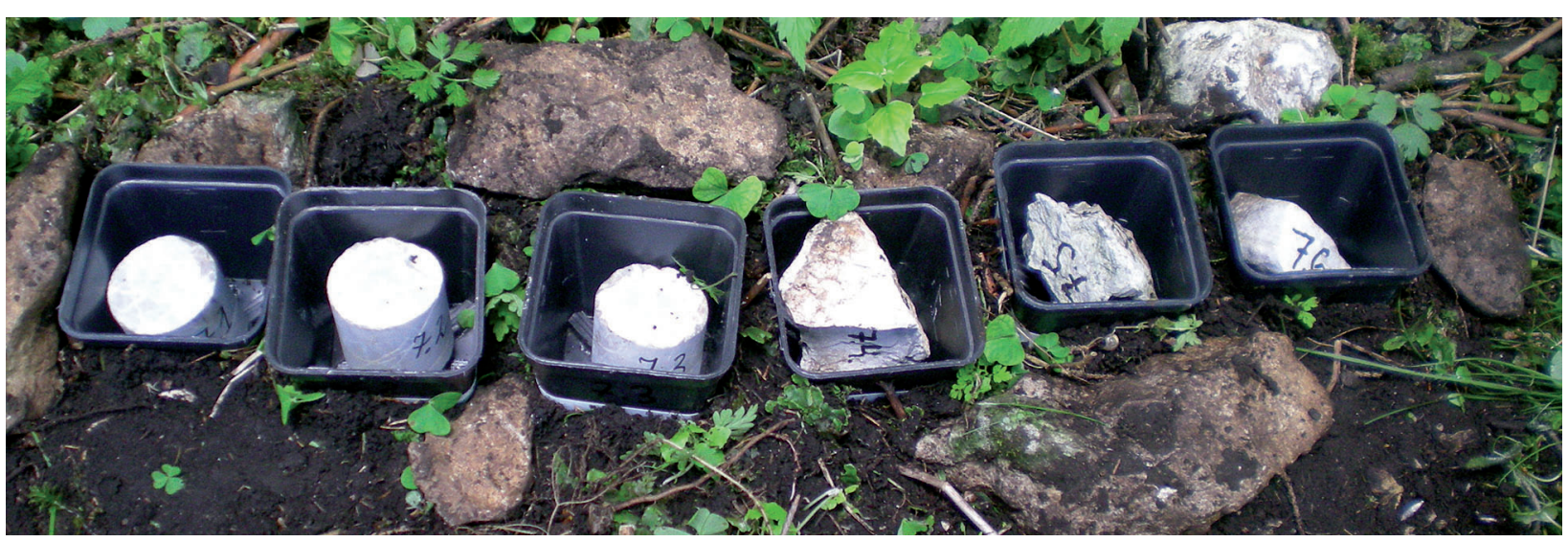

Fig. 4. Field experiment: measurement of weathering rates in natural conditions 

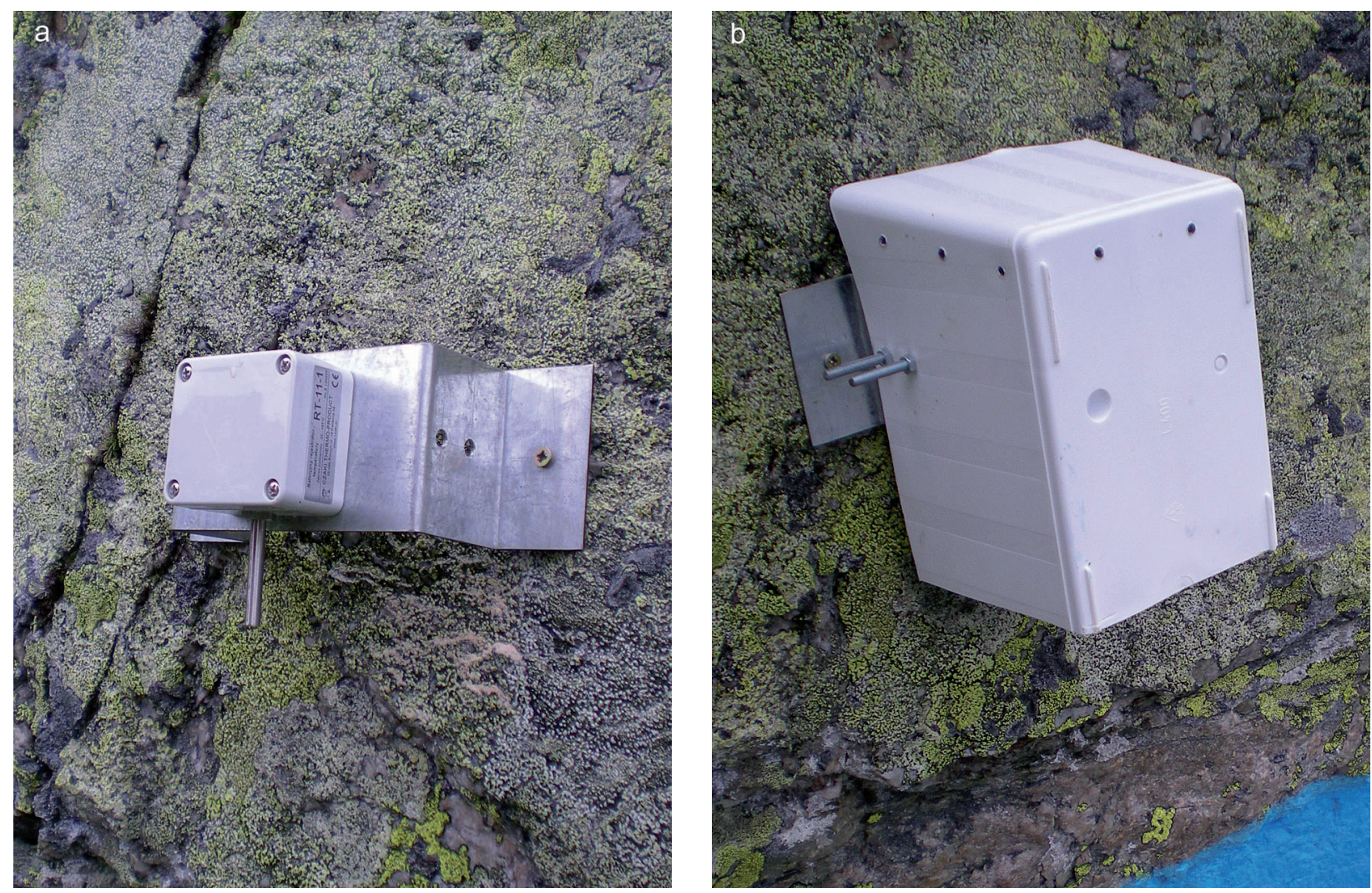

Fig. 5. Temperature recorders a) unshielded; b) shielded from sunlight

al count of the number of times that the freezing point is crossed. The measurement involves six battery-powered processor-equipped temperature recorders (Czaki Thermo Product RT-11) set to record measurements every 10 minutes with an accuracy of $0.1^{\circ} \mathrm{C}$. The devices are mounted using steel brackets at a height of one metre above the ground and about $5 \mathrm{~cm}$ away off the cliff face to ensure free air movement; and the whole shielded from sunlight. There is a mix of sites both above and below the tree line and sites on north and south-facing cliffs to cover a variety of thermal conditions (Table 6, Fig. 5).

Table 6. Temperature recorder sites

\begin{tabular}{|c|c|c|c|}
\hline Site & $\begin{array}{c}\text { Altitude } \\
\mathrm{m} \text { a.s.l. }\end{array}$ & Zone & Exposure \\
\hline Wołowiec & 1635 & Above treeline & $\mathrm{N}$ \\
\hline Mnichy Ch. & 1475 & Above treeline & $\mathrm{S}$ \\
\hline Mnichy Ch. & 1465 & Above treeline & $\mathrm{N}$ \\
\hline $\begin{array}{c}\text { Głębowiec } \\
\text { valley }\end{array}$ & 1030 & Below treeline & $\mathrm{S}$ \\
\hline $\begin{array}{c}\text { Głębowiec } \\
\text { valley }\end{array}$ & 1165 & Below treeline & $\mathrm{N}$ \\
\hline Grześ & 1175 & Below treeline & $\mathrm{S}$ \\
\hline
\end{tabular}

At this point, the duration of the field component of the study, which supplements the laboratory simulations, is not long enough for it to yield a meaningful result.

\section{Results}

\section{Physical properties of the samples tested}

The petrographic analysis provided detailed information about the mineral composition of the rocks and a photographic documentation from optical microscope observations at magnifications of $4 \times, 5 \times$ and $10 \times$. The quartzite sandstone (sample 2) was found to have directional texture with alternating fine and coarse-grain laminae, the grain structure mainly contained quartz with a silt binder that nearly completely filled the pores. The Tatra granites (samples 3 and 5) are quite similar to each other in terms of mineral composition, but the brown granite has a clearly directional texture. Their structure is holocrystalline, eurcrystalline, medium and coarse-crystalline, ranging from regular-crystalline to por- 
phyritic (the porphyry crystals are mostly white plagioclases). The samples are mainly composed of quartz, feldspar (plagioclases are more abundant than potassium feldspars) and muscovite. The amphibolite (sample 4) is fine-blastic, directional and with a nematogranoblastic structure. The mineral composition is dominated by amphiboles, plagioclases, biotite, chlorite and carbonates. The fine-grained conglomerate (sample 6) is compact and chaotic, mainly composed of quartz with isolated grains of feldspar. Nearly all the pores in this rock are filled with carbonaceous cement. The organic-detritic limestone (sample 7 ) is principally composed of crinoid fragments. The rock bears strong marks of tectonic activity with cracking derived from both expansion and shear forces.

An open porosity analysis yielded the following average figures: sample 1 (dolomite breccia) $3.87 \%$, sample 2 (quartzite sandstone) $0.69 \%$, sample 3 (white granite) $-1.50 \%$, sample 4 (amphibolite) $0.36 \%$, sample 5 (brown granite) $1.90 \%$, sample 6 (conglomerate) $2.59 \%$ and sample 7 (limestone) $1.17 \%$. All these results place the rocks in a class of low porosity, which is also characterised by a high resistance to frost weathering (Table 7).

The average volumetric density results include: sample $1-2.69 \mathrm{Mg} \mathrm{m}^{-3}$, sample $2-2.64 \mathrm{Mg}$

Table 7. Open porosity of rock samples

\begin{tabular}{|c|c|c|c|c|c|}
\hline Sample & $\begin{array}{c}\text { Porosi- } \\
\text { ty [\%] }\end{array}$ & Sample & $\begin{array}{c}\text { Porosi- } \\
\text { ty [\%] }\end{array}$ & Sample & $\begin{array}{c}\text { Porosi- } \\
\text { ty [\%] }\end{array}$ \\
\hline 1 & 3.43 & 3 & 2.00 & 5 & 1.09 \\
\hline 1 & 2.12 & 3 & 1.28 & 6 & 1.19 \\
\hline 1 & 2.06 & 3 & 1.37 & 6 & 1.42 \\
\hline 1 & 3.53 & 3 & 1.10 & 6 & 1.86 \\
\hline 1 & 6.47 & 4 & 0.31 & 6 & 2.88 \\
\hline 1 & 4.84 & 4 & 0.32 & 6 & 3.43 \\
\hline 1 & 4.62 & 4 & 0.28 & 6 & 2.40 \\
\hline 2 & 0.62 & 4 & 0.47 & 6 & 4.93 \\
\hline 2 & 0.67 & 4 & 0.26 & 7 & 1.21 \\
\hline 2 & 0.72 & 4 & 0.50 & 7 & 1.27 \\
\hline 2 & 0.85 & 5 & 2.52 & 7 & 1.27 \\
\hline 2 & 0.72 & 5 & 1.55 & 7 & 1.17 \\
\hline 2 & 0.58 & 5 & 2.02 & 7 & 1.02 \\
\hline 3 & 2.26 & 5 & 2.34 & 7 & 1.01 \\
\hline 3 & 1.31 & 5 & 2.21 & 7 & 1.24 \\
\hline 3 & 1.17 & 5 & 1.57 & & \\
\hline & & & & & \\
\hline
\end{tabular}

Table 8. Volumetric densities of rock samples

\begin{tabular}{|c|c|c|c|c|c|}
\hline $\begin{array}{c}\text { Sam- } \\
\text { ple }\end{array}$ & $\begin{array}{c}\rho \\
{\left[\mathrm{Mg} / \mathrm{m}^{3}\right]}\end{array}$ & $\begin{array}{c}\text { Sam- } \\
\text { ple }\end{array}$ & $\begin{array}{c}\rho \\
{\left[\mathrm{Mg} / \mathrm{m}^{3}\right]}\end{array}$ & $\begin{array}{c}\text { Sam- } \\
\text { ple }\end{array}$ & $\begin{array}{c}\rho \\
{\left[\mathrm{Mg} / \mathrm{m}^{3}\right]}\end{array}$ \\
\hline 1 & 2.71 & 3 & 2.58 & 5 & 2.60 \\
\hline 1 & 2.75 & 3 & 2.58 & 5 & 2.56 \\
\hline 1 & 2.70 & 3 & 2.64 & 5 & 2.59 \\
\hline 1 & 2.63 & 3 & 2,62 & 6 & 2.63 \\
\hline 1 & 2.68 & 4 & 2.90 & 6 & 2.56 \\
\hline 2 & 2.65 & 4 & 2.93 & 6 & 2.53 \\
\hline 2 & 2.65 & 4 & 2.90 & 6 & 2.53 \\
\hline 2 & 2.63 & 4 & 2.92 & 7 & 2.68 \\
\hline 2 & 2.64 & 4 & 2.68 & 7 & 2.67 \\
\hline 3 & 2.58 & 5 & 2.57 & 7 & 2.68 \\
\hline 3 & 2.60 & 5 & 2.60 & & \\
\hline
\end{tabular}

Table 9. Compressive (Rc) and tensile (Rr) strength

\begin{tabular}{|l|c|c|c|c|c|c|c|}
\hline Sample & 1 & 2 & 3 & 4 & 5 & 6 & 7 \\
\hline $\begin{array}{l}\text { Rc } \\
{[\mathrm{MPa}]}\end{array}$ & 77.6 & 405.3 & 284.2 & 167.2 & 217.1 & 368,2 & 77.4 \\
\hline $\begin{array}{l}\mathrm{Rr} \\
{[\mathrm{MPa}]}\end{array}$ & 7.2 & 7.4 & 6.4 & 13.6 & 6.8 & 18,1 & 5.2 \\
\hline
\end{tabular}

$\mathrm{m}^{-3}$, sample $3-2.60 \mathrm{Mg} \mathrm{m}^{-3}$, sample $4-2.87 \mathrm{Mg}$ $\mathrm{m}^{-3}$, sample $5-2.58 \mathrm{Mg} \mathrm{m}^{-3}$, sample $6-2.56 \mathrm{Mg}$ $\mathrm{m}^{-3}$ and sample $7-2.68 \mathrm{Mg} \mathrm{m}^{-3}$. Clearly this is not a differentiator in this study, as the densities are similar and all the rocks, even the densest amphibolite, fall within either the heavy or very heavy rock category (Table 8 ).

In terms of compressive and tensile strength the rocks belong to either a medium strength category (the carbonaceous rocks), or high to very high strength categories (the granites, amphibolite, conglomerate and sandstone, Table 9). Conglomerate and quartzite rocks displayed exceptionally high strength levels of $368.2 \mathrm{MPa}$ and $405.3 \mathrm{MPa}$, respectively, i.e. higher than most rocks (Table 4, 9). These high-pressure strength values translate into high resistance to frost weathering.

\section{The course and outcomes of frost weathering}

In the simulated frost weathering conditions individual grains started to fall off the samples tested within the first dozen or so cycles and the onset was the earliest in the carbonaceous and conglomerate samples. After approximately 40 cycles, the changes became bigger with fragments 

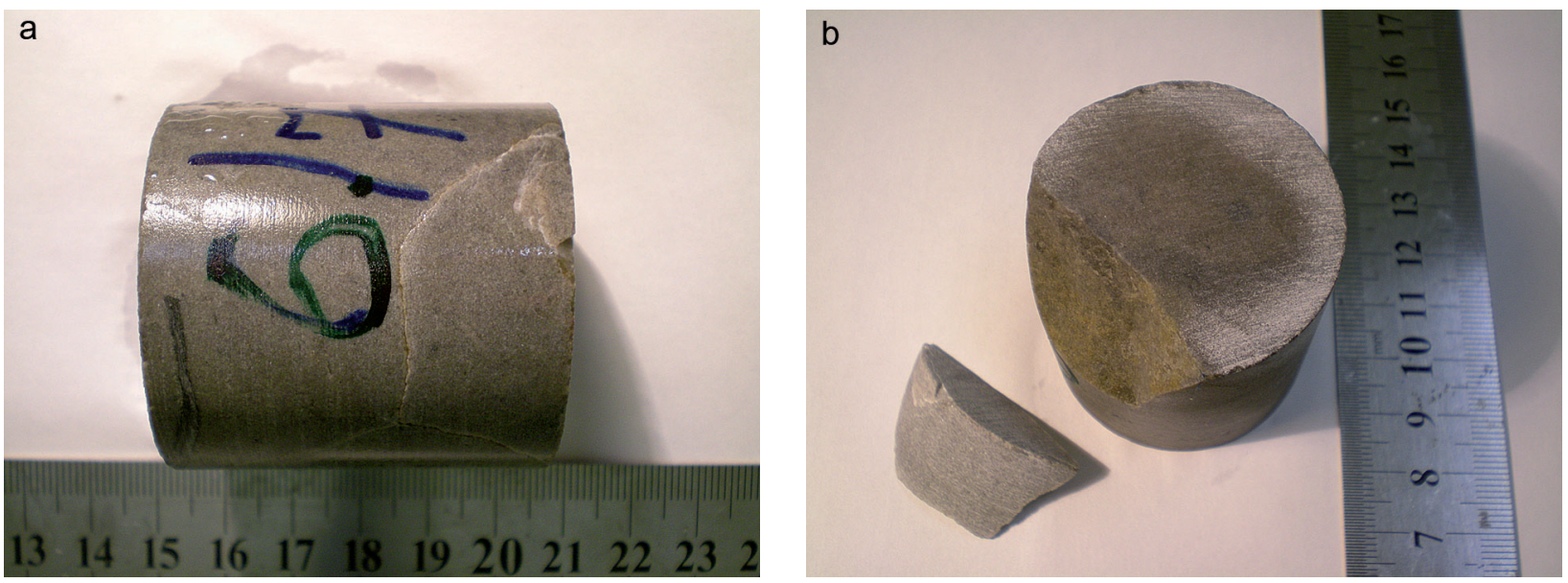

Fig. 6. Sample 6/7, a) initial condition, b) after 48 gelation cycles. The first digit denotes the rock type and the second denotes the sample number within the type, e.g. $6 / 7$, conglomerate sample 7

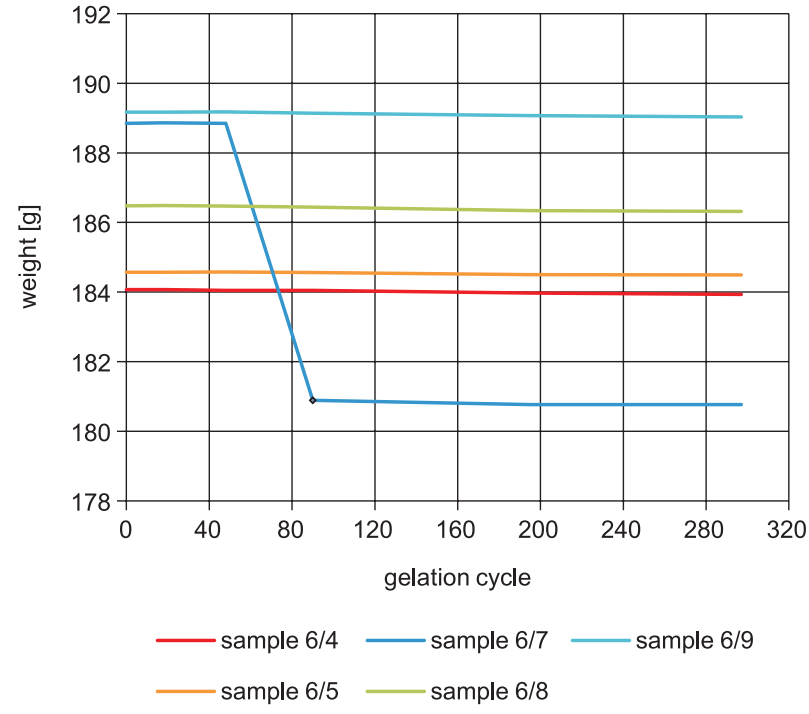

Fig. 7. Mass change of sample No. 6 during the course of the simulated frost weathering up to $9 \mathrm{~mm}$ in diameter falling off. After 48 cycles sample 6/7 (conglomerate) lost a fragment several centimetres in diameter with a weight of $7.96 \mathrm{~g}$, i.e. more than $4 \%$ of the sample's original weight (Fig. 6, 7). Soon after this event, more fragments measuring between $1 \mathrm{~mm}$ and upwards of $1 \mathrm{~cm}$ fell off the carbonaceous samples ( 1 and 7$)$ and the white granite (3). Subsequently, it took until after cycle 149 before another significant change occurred, when the dolomite sample $1 / 7$ shed a chunk from an edge measuring $4.0 \times 1.7 \times 1.5 \mathrm{~cm}$, as well as a number of smaller fragments, which brought the sample's weight down by ca. 10.57 g, i.e. $5.6 \%$ of its initial value (Figs 8,9 ). The occurrence of significant changes in the disintegration process then seemed to stop until cycle 308, when some fragments smaller than $1 \mathrm{~cm}$ fell off the same sample. No fragments were lost from the quartzite samples, while amphibolite and

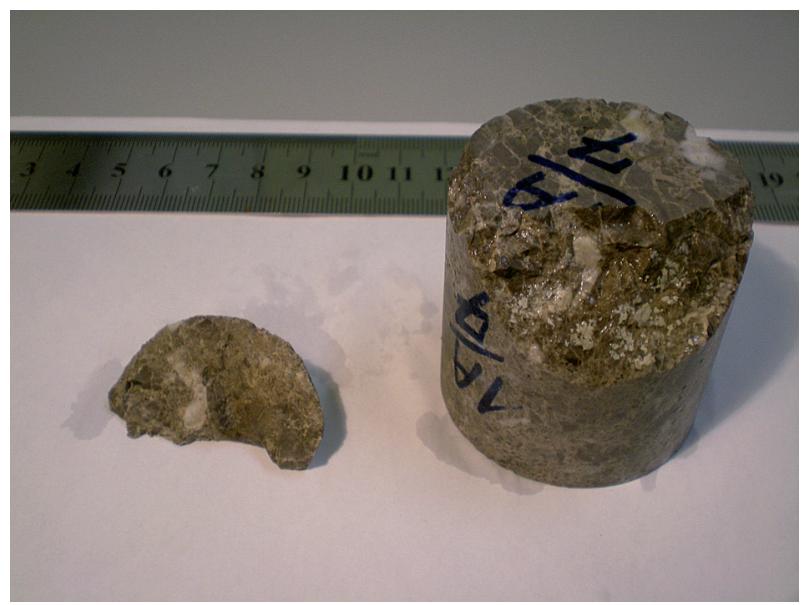

Fig. 8. Fragments fallen off sample 1/7 after 149 gelation cycles 


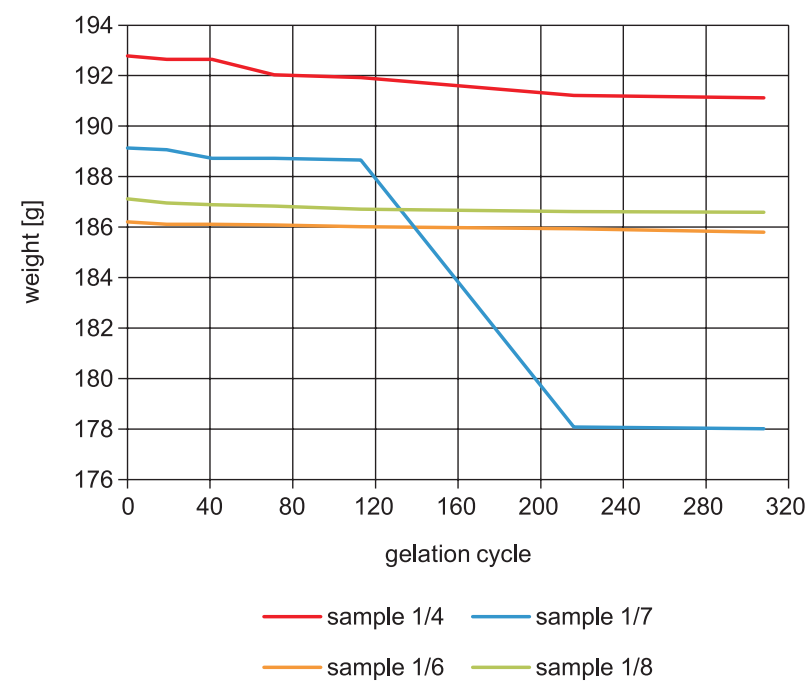

Fig. 9. Mass change in sample No. 1 during the course of the simulated frost weathering

brown granite produced small amounts of debris (Table 10).

The absorbability tests repeated during the laboratory experiment demonstrated marked changes in the rock samples after 300 gelation cycles. The values fluctuated within a small range and remained close to the pre-simulation level, which can be illustrated by the conglomerate sample (Fig. 10)

In most of the samples $(2,4,6$ and 7$)$ the fluctuation in ultrasound velocity was very low

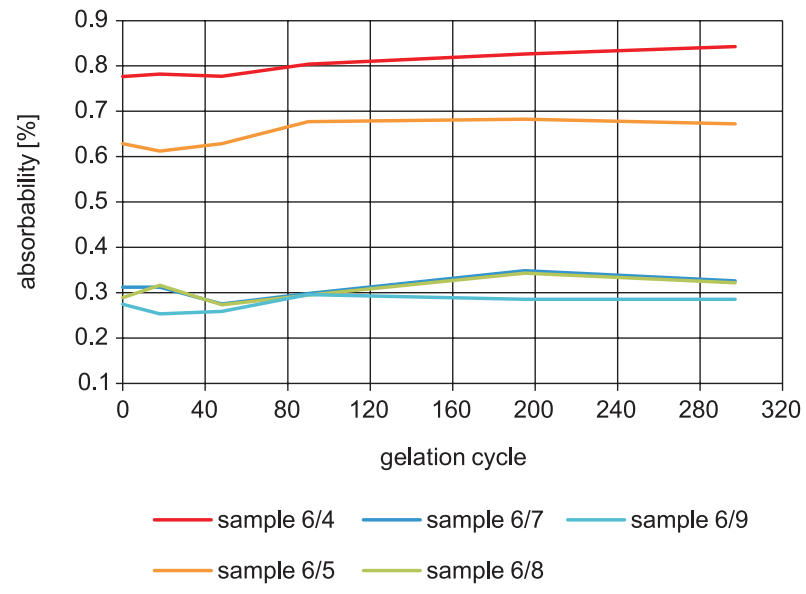

Fig. 10. Change in absorption capacity of sample No. 6 during the course of the simulated frost weathering

and within the margin of error of the method of measurement (Fig. 11), but a discernible trend for the velocity to fall was found in the dolomite and granite samples (1, 3 and 5$)$. The change is particularly strong in the brown granite sample where the velocity value was measured to drop from 4.47-4.71 $\mathrm{km} \mathrm{s}^{-1}$ to $4.15-4.46 \mathrm{~km} \mathrm{~s}^{-1}$ (Fig. 12). Any drop in the ultrasound wave propagating through the sample is evidence of damage to its internal structure.

SEC measurements in the wet containers, performed at the same time as the ultrasound velocity tests, showed an overall increase in values, but

Table 10. Quantitative changes in rock samples after 300 gelation cycles

\begin{tabular}{|c|c|c|c|c|c|c|c|c|c|c|}
\hline \multicolumn{2}{|c|}{ Sample No } & $1 / 4$ & $1 / 6$ & $1 / 7$ & $1 / 8$ & $2 / 2$ & $2 / 3$ & $2 / 4$ & $2 / 5$ & $2 / 6$ \\
\hline \multicolumn{2}{|c|}{ Initial weight $[\mathrm{g}]$} & 192.78 & 186.21 & 189.13 & 187.12 & 189.63 & 186.63 & 190.48 & 185.73 & 186.31 \\
\hline \multicolumn{2}{|c|}{ Debris weight $[\mathrm{g}]$} & 1.66 & 0.41 & 11.12 & 0.54 & 0.00 & 0.00 & 0.00 & 0.00 & 0.00 \\
\hline \multicolumn{2}{|c|}{ Proportion [\%] } & $0.86 \%$ & $0.22 \%$ & $5.88 \%$ & $0.29 \%$ & $0.00 \%$ & $0.00 \%$ & $0.00 \%$ & $0.00 \%$ & $0.00 \%$ \\
\hline $3 / 2$ & $3 / 3$ & $3 / 4$ & $3 / 5$ & $3 / 6$ & $4 / 2$ & $4 / 3$ & $4 / 4$ & $4 / 5$ & $5 / 2$ & $5 / 3$ \\
\hline 182.97 & 183.6 & 183.2 & 162.02 & 184.98 & 206.23 & 204.16 & 202.39 & 207.48 & 182.92 & 184.11 \\
\hline 0.07 & 0.40 & 0.06 & 0.13 & 0.40 & 0.15 & 0.15 & 0.14 & 0.15 & 0.00 & 0.05 \\
\hline $0.04 \%$ & $0.22 \%$ & $0.03 \%$ & $0.08 \%$ & $0.22 \%$ & $0.07 \%$ & $0.07 \%$ & $0.07 \%$ & $0.07 \%$ & $0.00 \%$ & $0.03 \%$ \\
\hline $5 / 4$ & $5 / 5$ & $6 / 4$ & $6 / 5$ & $6 / 7$ & $6 / 8$ & $6 / 9$ & $7 / 1$ & $7 / 2$ & $7 / 5$ & $7 / 7$ \\
\hline 183.86 & 183.44 & 184.07 & 184.57 & 188.85 & 186.48 & 189.17 & 181.35 & 156.31 & 184.98 & 179.73 \\
\hline 0.00 & 0.00 & 0.14 & 0.08 & 8.08 & 0.16 & 0.14 & 0.84 & 0.18 & 0.40 & 0.30 \\
\hline $0.00 \%$ & $0.00 \%$ & $0.08 \%$ & $0.04 \%$ & $4.28 \%$ & $0.09 \%$ & $0.07 \%$ & $0.46 \%$ & $0.12 \%$ & $0.22 \%$ & $0.17 \%$ \\
\hline
\end{tabular}




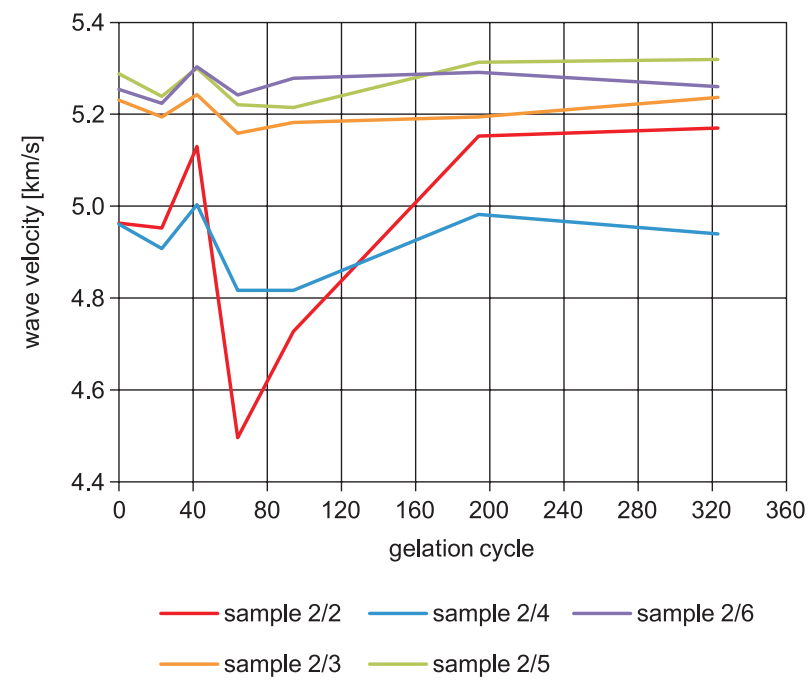

Fig. 11. Change in the velocity of a longitudinal wave during the course of the simulated frost weathering Sample

the rate of that change went from rapid early on to much more steady at a later stage, as illustrated by the example of the brown granite samples. During more than 300 gelation cycles SEC went up from $4.25 \mu \mathrm{S} \mathrm{cm} \mathrm{cm}^{-1}$ to $70-80 \mu \mathrm{S} \mathrm{cm} \mathrm{cm}^{-1}$, while the reference sample without a rock reached 5.13 $\mu \mathrm{S} \mathrm{cm}^{-1}$ (Fig. 13). This overall pattern was accompanied by considerable differences between samples. After more than 300 gelation cycles, the mean value in the quartzite sandstone was $40 \mu \mathrm{S}$ $\mathrm{cm}^{-1}$, in the granite samples $60-80 \mu \mathrm{S} \mathrm{cm}^{-1}$, but in the carbonaceous rocks they ranged from 169.3 to $282.7 \mu \mathrm{S} \mathrm{cm} \mathrm{cm}^{-1}$. An analysis of the ion composition of the water showed that $\mathrm{Ca}^{++}$was the main

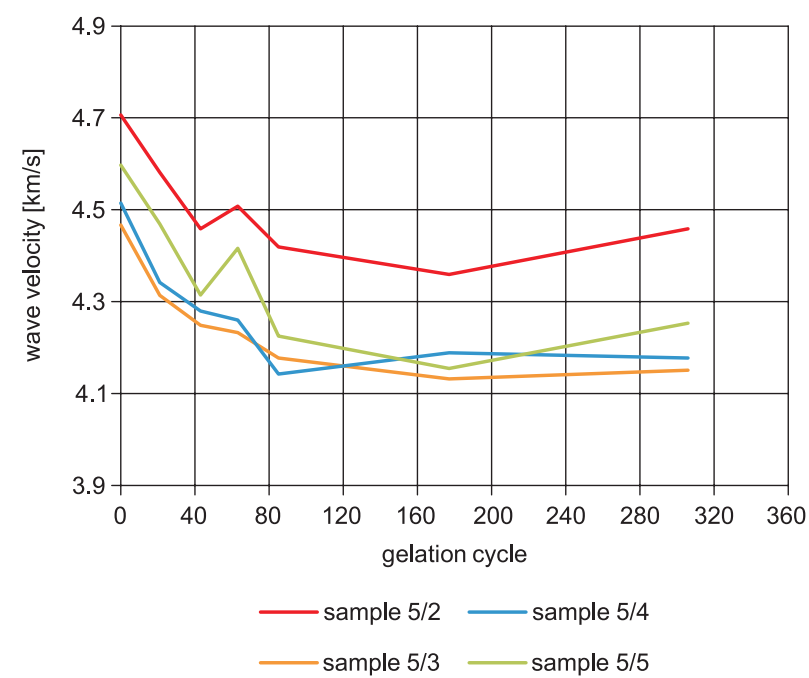

Fig. 12. Change in the longitudinal wave velocity during the course of the simulated frost weathering - Sample

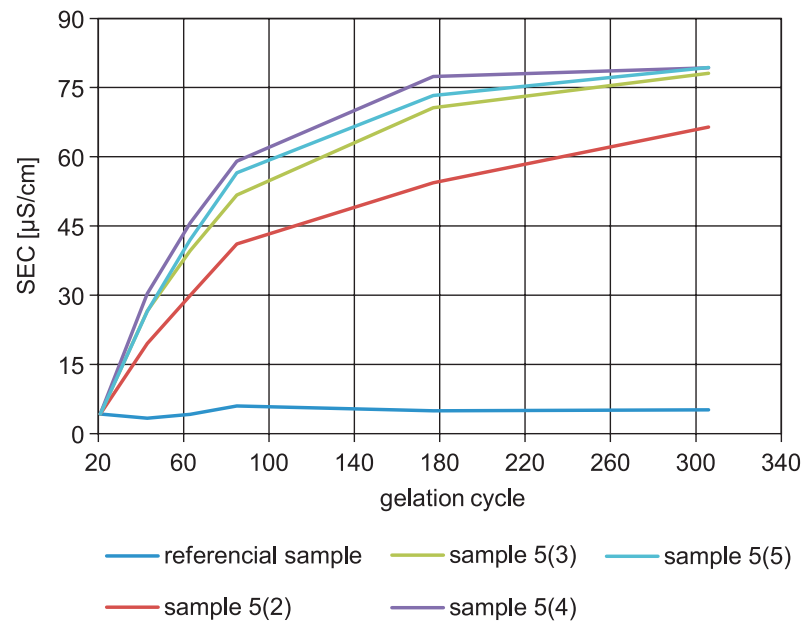

Fig. 13. SEC change during the simulated frost weathering - Sample

cation dissolved, followed by the $\mathrm{Mg}^{++}$cation in the dolomite samples. The dolomites featured the highest level of dissolution, followed by amphibolites, conglomerates and limestones. This is explained by the presence of carbonates in the petrographic composition of amphibolites and of carbonate fragments and carbonate cement in conglomerates. Among anions, chlorides and sulphates were the most dissolved and again dolomites were the rocks that dissolved the most.

\section{Conclusions}

The results of the laboratory testing demonstrated that all the rock types studied had low susceptibility to frost weathering. The most susceptible of them was dolomite breccia, where changes in the samples were detectable both with the naked eye and in ultrasound measurements. The granites primarily display changes to the structure as measured by the ultrasound waves, while little change is visible to the naked eye. So far quartzite and amphibolite rocks have proven the most resistant. The organic-detrital limestones, despite their considerable degree of cracking, including tectonic cracking, have shown little damage. This could be explained by the very low porosity of these rocks, by the resealing of the cracking with calcite and the presence of quartz in the mineral composition of the rock.

The results obtained so far are comparable with the results of frost weathering simulations by Evin (1987) and Lautridou, Ozouf (1982). The 
metamorphic rocks are highly resistant, sedimentary rocks and granites have produced minor quantities of waste rock, while carbonate rocks have shown the highest rate and scale of change. The lack of any similar research on Tatra rocks and the fact that the simulation conditions in various laboratories differed significantly (temperature ranges, cycle time and sample size) mean that only relative comparisons can be made between the rocks and main relationships identified.

The significant level of resistance in Tatra rocks demonstrated by the study is caused by their low open porosity, which normally remains within $5 \%$, by their mostly very high tensile and compressive strength and by low initial cracking. In many of the rocks there were also cements that filled most of the pores (carbonate cement in conglomerates and quartzite and silty cement in sandstones) and considerable quantities of quartz, mica and other minerals that are highly resistant to physical weathering. For breakup processes to develop in rocks with these physical properties the rocks require initial cracking. In the dolomite and limestone samples, and to a lesser extent in the conglomerate samples, solubility played a major role during the simulation. The study demonstrated a high influence of porosity and solubility behaviour on the susceptibility to frost weathering.

The laboratory simulation of frost weathering has provided within a short time time-scale the kind of information that fieldwork would produce in more than ten years. This laboratory exercise, alongside qualitative information, allows the quantification of the frost weathering process through the $\mathrm{R}_{\mathrm{f}}$ indicator calculated at the end of the experiment and the weight loss of each sample. Certain information is omitted from the simulation tests, however, and fieldwork is necessary to capture these factors that also influence the rate of rock breakup. The ultrasound measurements carried out as part of the experiment help captures changes within the rocks that are not visible to the naked eye, but would produce visible effects in the longer term.

\section{Acknowledgements}

The study is financed from a research budget of the Ministry of Science and Higher Education under the research projects No. N N306 257539. I am grateful to the Tatra National Park for allowing me to conduct fieldwork in the Chochołowska Valley.

\section{References}

André M.F., 1996. Rock weathering rates in arctic and subarctic environments (Abisko Mts., Swedish Lappland). Z. Geomorph. N.F. 40(4): 499-517.

Andrén A., 2006. Degradation of Rock and Shotcrete Due to Ice Pressure and Frost Shattering. Luleå University of Technology 19: 24-25.

Baranowska J., Garbiak M., 1999. Badania ultradźwiękowe (Ultrasonic tests). Politechnika Szczecińska, Szczecin.

Bland W., Rolls D., 1998. Weathering: An Introduction to the Scientific Principles. Oxford. University Press, New York.

Chen T.C., Yeung M.R., Mori N., 2004. Effect of water saturation on deterioration of welded tuff due to freeze-thaw action. Cold Regions Science and Technology 38: 127-136.

Everett D.H., 1961. The thermodynamics of frost damage to porous solids. Transactions Faraday Society 57: 1541-1551.

Evin M., 1987. Lithology and Fracturing control of rock glaciers in southwestern Alp of France and Italy. In: J.R. Giardino, J.F. Shorder, J.D. Vitek (ed.), Rock Glaciers. Allen \& Unwin, London, Wellington, Sydney: 83-160.

Hall K., 1992. Mechanical Weathering in the Antarctic: A Maritime Perspective. In: J.C. Dixon, A.D. Abrahams (eds), Periglacial Geomorphology. John Wiley \& Sons, Chichester, New York, Brisbane, Toronto, Singapore: 103-123.

Hall K., 1999. The role of thermal stress fatigue in the breakdown of rock in cold regions. Geomorphology 31: 47-63.

Hall K., Thorn C., 2010. The historical legacy of spatial scales in freeze-thaw weathering: Misrepresentation and resulting misdirection. Geomorphology 130: 83-90.

Hall K., Thorn C.E., Matsuoka N., Prick A., 2002. Weathering in cold regions: some thoughts and perspectives. Progress in Physical Geography 26 (4): 577-603.

Kisiel I., 1982. Mechanika skał i gruntów (Rock and ground mechanics). Wydawnictwo PWN, Warszawa.

Kotarba A., 2002. Współczesne przemiany przyrody nieożywionej w Tatrzańskim Parku Narodowym (Present transformation of inanimate nature in Tatra National Park). In: W. Borowiec, A. Kotarba, A. Kownacki, Z. Krzan, Z. Mirek (eds) Przemiany środowiska przyrodniczego Tatr. Wydawnictwo Instytutu Botaniki PAN, KrakówZakopane: 13-19.

Lautridou J.P., Ozouf J.C., 1982. Experimental frost shattering: 15 years of research at the Centre de Géomorphologie du CNRS. Progress in Physical Geography 6(2): 215-232.

Martini A., 1967. Preliminary experimental studies on frost weathering of certain rock types from the West Sudetes. Biuletyn Peryglacjalny 16: 147-194.

Matsuoka N., 1990a. Mechanisms of rock breakdown by frost action: an experimental approach. Cold Regions Science and Technology 17(3): 253-270.

Matsuoka N., 1990b. The rate of bedrock weathering by frost action: field measurements and a predictive model. Earth Surface Processes and Landforms 15: 73-90. 
Matsuoka N., 1991. A Model of the Rate of Frost Shattering: Application to Field Data from Japan, Svalbard and Antarctica. Permafrost and Periglacial Processes 2: 271-281.

Matsuoka N., 2001. Microgelivation versus Macrogelivation: Towards Bridging the Gap between Laboratory and Field Frost Weathering. Permafrost Periglac. Process. 12: 299-313.

Michalik A., 1985. Geologia - litologia i stratygrafia (Geology - lithology and stratigraphy) 1:50 000. In: K. Trafas (ed.) Atlas Tatrzański Park Narodowy. Wydawnictwo TPN, PTPNoZ, Kraków-Zakopane.

Migoń P., 2006. Geomorfologia (Geomorphology). Wydawnictwo PWN, Warszawa: 78-86.

Murton J.B., Peterson R., Ozouf J.C., 2006. Bedrock Fracture by Ice Segregation in Cold Regions. Science 314: 11271129.

Nowakowski A., Młynarczuk M., Ratajczak T., Gustkiewicz J., 2003. Wpływ warunków termicznych na zmianę niektórych właściwości fizycznych i strukturalnych wybranych skał (Influence of thermal conditions on change of certain physical and structural properties of selected rocks). Prace Instytutu Mechaniki Górotworu PAN Kraków, 5: 29-32.
Prick A., Guglielmin M., Strini A., 2003. Rock Weathering in Central Spitsbergen and in Northern Victoria Land (Antarctica).

Selby M.J., 1993. Hillslope materials and processes. Oxford University Press, Oxford: 137-141.

Tricart J., 1960. Prace doświadczalne w zakresie zagadnienia wietrzenia mrozowego (Experimental studies on frost weathering). In: J. Tricart (ed.), Zagadnienia geomorfologiczne. Wydawnictwo PWN, Warszawa, 201-234.

Viman S., 1963. A preliminary study of experimental frost weathering. Geografiska Annaler 45.

Walder J., Hallet B., 1985. A theoretical model of the fracture of rock during freezing. Geological Society of America Bulletin 96(3): 336-346.

Warke P.A., 2000. Micro-environmental conditions and rock weathering in hot, arid regions, Recent advances in field and laboratory studies of rock weathering. Zeitschrirft fur Geomorphologie 120: 83-95.

Whalley W.B., Warke P.A., 2005. Weathering. In: R.C. Selley (ed.). Encyclopedia of Geology 5. Elsevier, Oxford: 581-590. 